\title{
Результаты исследования эмоциональной сферы детей старшего дошкольного возраста
}

\author{
Васильева В.С., студентка, \\ Технический институт (филиал) \\ Северо-Восточного федерального университета, г. Нерюнгри \\ E-mail: nollon@rambler.ru
}

Научный руководитель: к.n.н., доцент Иванова В.А.

Актуальность работы связана с тем, что развитие эмоциональной сферы является важнейшим аспектом развития личности в целом. Личностное и умственное развитие ребенка тесным образом связано с особенностями мира его чувств и переживаний. Дети часто находятся в «плену эмоций», поскольку еще не могут управлять своими чувствами, что приводит к импульсивности поведения, осложнениям в общении со сверстниками и взрослыми. Они не всегда способны осознавать и контролировать свои эмоции. Дети не всегда правильно понимают даже простые эмоции, тем более трудно им осознать те разнообразные переживания, которые возникают по мере расширения их связей с окружающим миром. Человек судит об эмоциональном состоянии другого по особым выразительным движениям, мимике, изменению голоса. Поза, жест, особенности движений во многом дополняют мимику и играют важную роль в передаче эмоционального состояния [2, с. 45].

Одним из методов развития эмоциональной сферы является игротерапия, в основе которого лежит игра. В связи с этим нами была сформулирована задача по изучению и развитию эмоциональной сферы детей старшего дошкольного возраста -систематизация средств игротерапии, направленных на развитие эмоциональной сферы детей.

Исследование проводилось на базе МБДОУ № 17 города Нерюнгри Нерюнгринского района. Всего в эксперименте участвовало 18 детей в возрасте 5-6 лет.

Экспериментальная работа проводилась в три этапа. На первом (констатирующем) этапе с 01.09.2016 г. по 14.10.2016 г. в группе была проведена первичная диагностика с целью изучения уровня развития эмоциональной сферы детей экспериментальной группы и были получены следующие результаты/

1. Методика «Изучение особенностей использования детьми мимики и пантомимики при демонстрации заданной эмоции» (В. М. Минаева) [1, с. 54].

Анализируя использование детьми выразительных средств при показе каждого эмоционального состояния, и сравнивая результаты первой и второй серии исследования, можно сказать, что в основном дети использовали мимику как средство для показа эмоционального состояния. При демонстрации веселого состояния 100\% (18 человек) показали мимикой в первой и второй серии задания, и смогли назвать персонажа. 50\% (9 человек) детей изобразили пантомимикой, так как наблюдение показывает, что им сложно было изображать эмоции движением тела и они стеснялись. Печаль смогли показать 80\% (14 человек) мимикой и 30\% (5 человек) пантомимикой. Испуг изобразили 100\% (18 человек) детей мимикой и 40\% (7 человек) пантомимикой. Сердитого персонажа 90\% (16 человек) мимикой и 30\% (5 человек) пантомимикой. Удивление 40\% (8 человек) мимикой и 17\% (3 человека) пантомимикой. В основном 
дети ориентировались в выборе персонажа из современных мультиков: «Человек-паук», «Головоломка», «Лунтик».

На основе полученных данных об особенностях использования детьми мимики и пантомимики при демонстрации эмоциональных состояний радости, грусти, страха, гнева, удивления было выявлено, что: наиболее сложным для мимического выражения оказалась эмоция «удивление» для 45 \% (8 человек), «печальный» 80\% (14 человек), и не вызвали трудности эмоции «сердитый» 90\% (15 человек), «веселый» 100\% (18 человек), «испуганный» 100\% (18 человек); наиболее сложным для пантомимического изображения оказалась эмоция «удивление» $17 \%$ (3 человека) (детям тяжело было справиться с данным заданием). Наименьшие трудности вызвали эмоции «испуганный», «веселый» 40\% (7 человек) и 50\% (9 человек) соответственно; при назывании и изображении веселого, печального, испуганного, сердитого, удивленного персонажей для детей наиболее сложным для предъявления оказался «удивленный» и «сердитый» персонажи 50\% (8 человек) и 50\% (8 человек) соответственно, а наиболее легким - был «веселый» персонаж 100\% (18 человек), «печальный» 80\% (14 человек) и «испуганный» $100 \%$ (18 человек).

Результаты исследования особенностей понимания детьми эмоциональных состояний людей свидетельствуют о том, что самым сложным для понимания оказалось состояние удивления для 50\% (9 человек), а менее сложным - состояние радости $100 \%$ (18 человек).

2. Методика «Изучение понимания детьми эмоциональных состояний людей» (В. М. Минаева) [1, с. 22].

Изучение понимания детьми эмоциональных состояний людей и своего эмоционального состояния показало, что дети в основном адекватно подбирали ситуацию, соответствующую заданному эмоциональному состоянию, за исключением таких эмоций как удивление 20\% (4 человека); горе 20\% (4 человека); удовольствие 25\% (5 человек). При выражении эмоций словами многие испытывали затруднения таких эмоциях, как удовольствие 10\% (2 человека); удивление 10\% (2 человека); горе $10 \%$ (2 человека); наибольшее количество правильных ответов отмечено при обозначении таких эмоций как страх 70\% (11 человек) и интерес 75\% (12 человек); радость 80\% (14 человек) и стыд $80 \%$ (14 человек).

3. Методика «Изучение понимания эмоциональных состояний людей, изображенных на картинке» (Г. А. Урунтаева) [2, с. 43].

Восприятие графических изображений эмоциональных состояний: «Радость», «Печаль», «Страх», «Гнев» не вызывало затруднений. Наиболее трудными для восприятия оказались графические изображения эмоционального состояния: «Удивление». При описании эмоций дети опирались на такие признаки, как глаза, губы, брови. Во второй серии заданий детям было сложно отвечать на вопросы по сюжетным картинкам (путали радость и грусть).

На втором (формирующем) этапе с 20.10.2016 г. по 20.03.2017 г. была составлена и апробируется психолого-педагогическая программа «Царство эмоций», направленная на развитие эмоциональной сферы детей старшего дошкольного возраста.

По завершению второго этапа исследования мы ожидаем получить следующие результаты: дети будут знать основные эмоции: радость, страх, гнев, грусть, удивление, отвращение, вина, стыд, презрение; будут иметь представление о способах выражения собственных эмоциональных состояниях; научатся понимать эмоционального состояния свои и окружающих людей; пополнится активный словарный запас словесными 
обозначениями эмоций; будут умение графически изображать заданную эмоцию и использовать мимику и пантомимику для передачи своей эмоции.

На занятиях мы используем следующие методы:

Игротерапия - это метод психотерапевтического воздействия с использованием игры. Игротерапия используется на каждом занятии и выбор упражнения зависит от цели занятия. Например, в занятии № 1 «Знакомство», используется игра «Испорченный телефон» с целью снятия напряжения и создания доброжелательной атмосферы. В занятии № 2 «Удивительный мир эмоций и чувств» используется игра «Встаньте все те кто...», которая поможет детям почувствовать себя непринужденно, будет способствовать развитию внимания, наблюдательности. В занятии № 3 «Наши чувства» упражнение «Чувство в домиках» способствует знакомству детей с графическим изображением эмоциональных состояний людей. В занятии № 5 «Эмоциональные состояние детей и взрослых» используем игру «Какое настроение» с целью научить распознавать эмоциональные проявления других людей по различным признакам (мимика, пантомимика, интонация). В занятии № 7 «Радость» применение игры «Кто как радуется» научит дошкольников изображать эмоцию «радость» в разных ситуациях. В занятии № 8 «Страх» с целью снятие страхов используется упражнение «Мусорное ведро». В занятии № 12 «Гнев» для понимания и контроля эмоции «гнев» используется игра «Зеркало». Игра «Сравни лицо» доступно покажет детям эмоцию «грусть» в занятие № 16 «Мы сегодня не грустим». В занятие № 17 «Удивление» игра «Круглые глаза», в свою очередь, поможет дошкольникам понять эмоцию «удивление».

Беседа - педагогический метод для передачи информации. На занятиях проводятся беседы на темы: «Удивительный мир эмоций и чувств» (занятие № 2) - «Что такое настроение, чувство, эмоции», «Школа настроений» (занятие № 4) - «Что такое жест», «Гнев» (занятие № 12) - «Что такое гнев», «Удивление» (занятие № 17) - «Как выглядит удивленный человек». Все эти беседы подробно раскрывают для детей тему эмоции.

Сказкотерапия - это метод, который помогает скорректировать психологические проблемы личности ребенка благодаря сказкам, волшебным историям, басням и былинам. В программе используется прием чтения сказок, так, например, в занятии № 2 «Удивительный мир эмоций и чувств» детям предлагается послушать сказку «Домовые», которая способствует знакомству с эмоциями «радость», «грусть», «злость», «страх».

Изотерапия - эффективный и действенный метод, который помогает ребенку справиться с негативными эмоциями, снять нервно-психическое напряжение. Например, в занятии № 9 «Маленький храбрец», применяется прием прорисовывания страхов «Мой страх». Цель данного приема - преодоление негативных переживаний. Рисование своего страха, рассказ о нем и способах его преодоления помогут ребенку старшего дошкольного возраста осознать то, чего он боится и справиться с этим.

Психогимнастика - невербальный метод, в основе которого лежит использование двигательной экспрессии в качестве главного средства коммуникации в группе. Например, для снятие мышечного и психологического напряжения, установление межличностных контактов используются релаксационные упражнения на занятиях: «Доброе животное», «Дождь в лесу», «Воздушный шарик», «Самолет».

Драматизация - инсценирование, проигрывание по ролям героев литературных произведений, чаще это могут быть сказки, песни, стишки. Например, в занятии «Мы сегодня не грустим», применяется этюд «Кролик и еж» с целью научить детей выражать чувства, эмоции и настроение. 
Мозговой штурм - метод решения проблемы на основе стимулирования творческой активности, при котором участникам обсуждения предлагают высказывать возможно большее количество вариантов решения, в том числе самых фантастических. При проведении мозгового штурма «Как побороть страх» в занятии № 9 «Маленький храбрец» детям предлагается поделиться собственным опытом в преодолении страха, затем психолог добавляет свои.

На третьем этапе 10.02.2017 г. была осуществлена промежуточная диагностика, результаты которой можно увидеть в таблице:

\begin{tabular}{|c|c|c|c|}
\hline $\begin{array}{l}\text { Название } \\
\text { методики }\end{array}$ & Параметры & $\begin{array}{l}\text { Первичное } \\
\text { исследование, \% }\end{array}$ & $\begin{array}{l}\text { Промежуточное } \\
\text { исследование, \% }\end{array}$ \\
\hline \multirow{12}{*}{$\begin{array}{l}\text { 1.«Изучение } \\
\text { особенностей } \\
\text { использования } \\
\text { детьми мимики и } \\
\text { пантомимики при } \\
\text { демонстрации } \\
\text { заданной } \\
\text { эмоции» (В. М. } \\
\text { Минаева) }\end{array}$} & $\begin{array}{l}\text { Серия } 1 \\
\text { Мимика: }\end{array}$ & & \\
\hline & Веселый & 100\% (18 человек) & 100\% (человек) \\
\hline & Печальный & 80\% (14 человек) & 90\% (16 человек) \\
\hline & Испуганный & 100\% (18 человек) & 100\% ( 18 человек) \\
\hline & Сердитый & 90\% (16 человек) & 100\% (18 человек) \\
\hline & Удивленный & 45\% (8 человек) & 60\% (10 человек) \\
\hline & $\begin{array}{l}\text { Серия } 2 \\
\text { Пантомимика: }\end{array}$ & & \\
\hline & Веселый & 50\% (9 человек) & 70\% (11 человек) \\
\hline & Печальный & 25\% (5 человек) & 50\% (9 человек) \\
\hline & Испуганный & 40\% (7 человек) & 60\% (10 человек) \\
\hline & Сердитый & 25\% (5 человек) & 60\% (10 человек) \\
\hline & Удивленный & 17\% (3 человека) & 40\% (7 человек) \\
\hline \multirow{18}{*}{$\begin{array}{l}\text { 2.«Изучение } \\
\text { понимания } \\
\text { детьми } \\
\text { эмоциональных } \\
\text { состояний } \\
\text { людей» (В. М. } \\
\text { Минаева) }\end{array}$} & Серия 1 & & \\
\hline & Интерес & 70\% (11 человек) & 85\% (15 человек) \\
\hline & Удивление & 20\% (4 человека) & 40\% (7 человек) \\
\hline & Удовольствие & 25\% (5 человек) & 30\% (6 человек) \\
\hline & Стыд & 75\% (12 человек) & 90\% (16 человек) \\
\hline & Страх & 60\% (10 человек) & 80\% (14 человек) \\
\hline & Злость & 55\% (9 человек) & 70\% (11 человек) \\
\hline & Радость & 80\% (14 человек) & 90\% (16 человек) \\
\hline & Гope & 20\% (4 человека) & 50\% (9 человек) \\
\hline & Серия 2 & & \\
\hline & Интерес & 75\% (12 человек) & 85\% (15 человек) \\
\hline & Удивление & 10\% (2 человека) & 40\% (7 человек) \\
\hline & Удовольствие & 10\% (2 человека) & 40\% (7 человек) \\
\hline & Стыд & 80\% (14 человек) & 90\% (16 человек) \\
\hline & Страх & 70\% (11 человек) & 90\% (16 человек) \\
\hline & Злость & 60\% (10 человек) & 80\% (14 человек) \\
\hline & Радость & 80\% (14 человек) & 90\% (16 человек) \\
\hline & Гope & 10\% (2 человека) & 40\% (7 человек) \\
\hline \multirow{3}{*}{$\begin{array}{l}\text { 3.«Изучение } \\
\text { понимания } \\
\text { эмоциональных }\end{array}$} & Гнев & 70\% (11 человек) & 85\% (15 человек) \\
\hline & Гope & 50\% (9 человек) & 70\% (11 человек) \\
\hline & Печаль & 77\% (13 человек) & 85\% (15 человек) \\
\hline
\end{tabular}




\begin{tabular}{|l|l|l|l|}
\hline состояний людей, & Радость & $100 \%$ (18 человек) & $100 \%$ (18 человек) \\
\cline { 2 - 4 } $\begin{array}{l}\text { изображенных на } \\
\text { картинке» (Г. А. }\end{array}$ & Удивление & $42 \%$ (8 человек) & $60 \%$ (10 человек) \\
\cline { 2 - 4 } \begin{tabular}{l} 
Урунтаева) \\
\cline { 2 - 4 }
\end{tabular} & Страх & $70 \%$ (11 человек) & $90 \%$ (16 человек) \\
\hline
\end{tabular}

Таким образом, очевидно, что у всех детей старшего дошкольного возраста экспериментальной группы наблюдается улучшение результатов диагностики, а занятия по психолого-педагогической программе «Царство эмоций» оказывает положительное влияние на развитие эмоциональной сферы у детей старшего дошкольного возраста.

Итак, по результатам проведенного исследования, можно сделать вывод, что данная программа способствует развитию эмоциональной сферы у детей старшего дошкольного возраста.

Список литературы: $512 \mathrm{c}$.

1. Осипова А.А. Общая психокоррекция. учебное пособие. - М.: Сфера, 2007. -

2. Урунтаева Г.А. Диагностика психологических особенностей дошкольника. М.: Академия, 1996. - 96 с.

\section{Роль традиционного костюма в формировании основных направлений современной моды в Якутии}

Васильева М.С., Северо-Восточный федеральный университет, 2. Якутск

Научный руководитель: стариий преподаватель Прокопьева А.Н.

В настоящее время в социокультурном пространстве всего российского общества возрос интерес к истории своей национальной культуры. Одним из самобытных народов России, активно развивающих свою уникальную культуру, являются якуты. Наряду с возрождением языка, религии, национальных традиций большое внимание уделяется материальной культуре, одним из основных объектов которой выступает костюм. Сейчас в Якутии ведется всесторонняя популяризация одежды, выполненной в национальном стиле. Для современных дизайнеров обращение к традициям создания национального костюма становится источником вдохновения при моделировании современной модной одежды. Однако, на сегодняшний день, перед исследователями истории моды встают вопросы, связанные с историей национального костюма и его влиянием на развитие современной моды. Кроме того, требует изучения вопрос значимости богатства национального костюма в разработке уникальных образцов одежды, сочетающих в себе современные модные направления с использованием элементов моделирования традиционного костюма.

Цель работы: На основе работ якутских дизайнеров, проследить использование народных мотивов. 